ZOOLOGIA 30 (1): 80-87, February, 2013

http://dx.doi.org/10.1590/S1984-46702013000100010

\title{
Molecular evidence for the polyphyly of Bostryx (Gastropoda: Bulimulidae) and genetic diversity of Bostryx aguilari
}

\author{
Jorge L. Ramirez ${ }^{1,2}$ \& Rina Ramírez ${ }^{1}$
}

\author{
${ }^{1}$ Departamento de Malacología y Carcinología, Museo de Historia Natural, Universidad Nacional Mayor de San Marcos, \\ Apartado 14-0434, Lima-14, Perú. \\ ${ }^{2}$ Coresponding author. E-mail: jolobio@hotmail.com
}

\begin{abstract}
Bostryx is largely distributed in Andean Valleys and Lomas formations along the coast of Peru and Chile. One species, Bostryx aguilari, is restricted to Lomas formations located in the Department of Lima (Peru). The use of genetic information has become essential in phylogenetic and population studies with conservation purposes. Considering the rapid degradation of desert ecosystems, which threatens the survival of vulnerable species, the aim of this study was, first, to resolve evolutionary relationships within Bostryx and to determine the position of Bostryx within the Bulimulidae, and second, to survey the genetic diversity of Bostryx aguilari, a species considered rare. Sequences of the mitochondrial 16S rRNA and nuclear rRNA regions were obtained for 12 and 11 species of Bulimulidae, respectively, including seven species of Bostryx. Sequences of the 16S rRNA gene were obtained for 14 individuals (from four different populations) of Bostryx aguilari. Phylogenetic reconstructions were carried out using Neighbor-Joining, Maximum Parsimony, Maximum Likelihood and Bayesian Inference methods. The monophyly of Bostryx was not supported. In our results, $B$. solutus (type species of Bostryx) grouped only with B. aguilari, B. conspersus, B. modestus, B. scalariformis and B. sordidus, forming a monophyletic group that is strongly supported in all analyses. In case the taxonomy of Bostryx is reviewed in the future, this group should keep the generic name. Bostryx aguilari was found to have both low genetic diversity and small population size. We recommend that conservation efforts should be increased in Lomas ecosystems to ensure the survival of $B$. aguilari, and a large number of other rare species restricted to Lomas.
\end{abstract}

KEY WORDS. Land snails; Lomas; molecular systematic; Orthalicoidea; rRNA.

Among Neotropical land snails, Bulimulidae is one of the most diverse (BREURE 1979, RAMírez et al. 2003a). The phylogenetic relationships among its members, however, are still problematic. Genera such as Bostryx and Scutalus are distributed in desert ecosystems and are adapted to survive under some of the harshest climatic conditions (Aguilar \& Arrarte 1974, Ramírez et al. 2003b). Bostryx is found in Argentina, Bolivia, Chile, Peru, Ecuador, and possibly in Venezuela (Breure 1979). It is spread throughout Peru, but is more prevalent in the Pacific coastal desert and the western Andean slopes (RAmírez et al. 2003a). Among the Bostryx species, B. aguilari Weyrauch, 1967 (Fig. 2) is of particular interest, due to its vulnerable status and lack of information on the genetic diversity of its populations. It is a species associated with bushy Lomas and is found at elevations of 200 to $600 \mathrm{~m}$. Bostryx aguilari was originally reported for the Lomas of Amancaes, Atocongo and Pachacamac, but there is also a record of an unknown locality near the city of Junín, in the Peruvian Andes (Weyrauch 1967). To date, this species has been reported for at least 12 Lomas in the Department of Lima, and is distributed from the Lomas of Lachay, in the north, to the Lomas of Pacta, in the south (R. Ramírez unpublished data). Bostryx aguilari, unlike other gastropod species of Lomas, is very difficult to find, not only alive, but also as shell remnant. An exception is the Lomas of Atocongo, where B. aguilari can be found more easily. The Lomas formations are seasonal ecosystems occurring along the coast of Peru and Chile, between $8^{\circ}$ and $30^{\circ}$ SL (RUNDel et al. 1990), where the main source of humidity are fogs brought from the Pacific Ocean during the winter months (Dillon et al. 2003). Periodically (every few years), the El Niño-Southern Oscillation (ENSO) alters the seasonality of the Lomas, causing summer drizzles that promote the development of out of season vegetation. The steady growth of cities is threatening the biodiversity in desert ecosystems, and particularly the Lomas, which are still poorly known and described. They are beginning to disappear at a fast pace, and with them, their endemic species. Our objectives are to resolve evolutionary relationships within Bostryx to clarify the position of the genus among the Bulimulidae, and to survey the genetic diversity of B. aguilari, a rare species threatened by loss of habitat and human pressure. Because the maintenance of genetic diversity is vital to the survival of populations and species, this information will be crucial to the establishment of guidelines for the conservation of $B$. aguilari and for the Lomas ecosystems they inhabit. 


\section{MATERIAL AND METHODS}

Species of Bostryx were collected from several Peruvian localities comprising Lomas, Inter-Andean valleys and tropical forests (Table I). We also included species of Scutalus, Drymaeus, Naesiotus and Neopetraeus as outgroups (Table I and Figs 1-12). Samples were fixed in $96 \%$ ethanol and deposited in the collection at Department of Malacology and Carcinology, Museum of Natural History, San Marcos University. Individuals of $B$. aguilari were obtained from seven Lomas, all located in the Department of Lima in the central coast of Peru (Amancaes, Atocongo, Iguanil, Lúcumo, Manzano, Paraíso and Picapiedra), although live specimens were only found in three locations (Amancaes, Atocongo and Iguanil).

DNA was isolated using a modified CTAB method (DoyLE $\&$ Doyle 1987) from $1-2 \mathrm{~mm}^{3}$ of tissue from the snail foot. The tissue sample was digested in $300 \mu \mathrm{L}$ of extraction buffer (100 $\mathrm{mM}$ Tris/ $\mathrm{HCl}, 1.4 \mathrm{M} \mathrm{NaCl}, 20 \mathrm{mM}$ EDTA, 2\% CTAB, 2\% PVP and $0.2 \%$ of $\beta$-mercaptoethanol) with $0.05 \mathrm{mg}$ Proteinase $\mathrm{K}$ and incubated at $60^{\circ} \mathrm{C}$ for approximately two hours. Proteins were removed twice with $310 \mu \mathrm{L}$ of chloroform/isoamyl alcohol (24:1), centrifugation was at 13,000 rpm for 15 minutes before removal of the aqueous phase. The DNA was precipitated using $600 \mu \mathrm{L}$ of cold absolute ethanol and $25 \mu \mathrm{L}$ of $3 \mathrm{M}$ ammonium acetate and incubated at $-20^{\circ} \mathrm{C}$ for at least $30 \mathrm{~min}-$ utes, then centrifuged at $13,000 \mathrm{rpm}$ for $15 \mathrm{~min}$. The pellet obtained was washed twice in $1 \mathrm{~mL}$ of $70 \%$ ethanol and centri- fuged at 13,000 rpm for $15 \mathrm{~min}$. Finally, the pellet was dried at room temperature for 24 hours, resuspended in $50 \mu \mathrm{L}$ of doubledistilled water at $37^{\circ} \mathrm{C}$, and stored at $-20^{\circ} \mathrm{C}$.

Using total genomic DNA, we amplified and sequenced the 16S rRNA gene and the rRNA gene-cluster. Amplifications were carried out using the polymerase chain reaction (PCR) (SAIKI et al. 1988). For the amplification of the 16S rRNA gene, we used primers developed by (R. Ramírez unpublished data): 16SF-104 (5'-GACTGTGCTAAGGTAGCATAAT-3') and 16SR-472 (5'-TCGTAGTCCAACATCGAGGTCA-3'). To obtain the nuclear rRNA gene-cluster, including the 3 '-end of the 5.8S rRNA gene, the complete internal transcribed spacer 2 (ITS-2) region, and the 5 '-end of the large subunit (28S rRNA) gene, we used primers LSU1 and LSU3 developed for mollusks by WADE \& MoRDAN (2000).

For the $16 \mathrm{~S}$ rRNA, PCR amplification were performed in a final volume of $30 \mu \mathrm{L}$, containing $1 \mathrm{U}$ of Taq DNA polymerase (Fermentas Inc., Maryland, US), $1.5 \mathrm{mM} \mathrm{MgCl}_{2}, 0.2 \mathrm{mM} \mathrm{dNTP}$ and $0.2 \mathrm{iM}$ of each primer, $1 \mathrm{X}$ buffer, and $3 \mu \mathrm{L}$ of DNA template. Amplifications consisted of 35 cycles of denaturation at $94^{\circ} \mathrm{C}$ for 30s, annealing at $48^{\circ} \mathrm{C}$ for $30 \mathrm{~s}$, and extension at $72^{\circ} \mathrm{C}$ for 60 s. PCR reagents used for the amplification of nuclear markers were the same as above; amplifications consisted of 35 cycles of $96^{\circ} \mathrm{C}$ for $60 \mathrm{~s}, 50-55^{\circ} \mathrm{C}$ for 30 s and $72^{\circ} \mathrm{C}$ for 60 s. Amplicons were electrophoresed on $1 \%$ agarose gels to verify the amplification. PCR products were purified and sequenced for both strands using the commercial services at Macrogen USA.
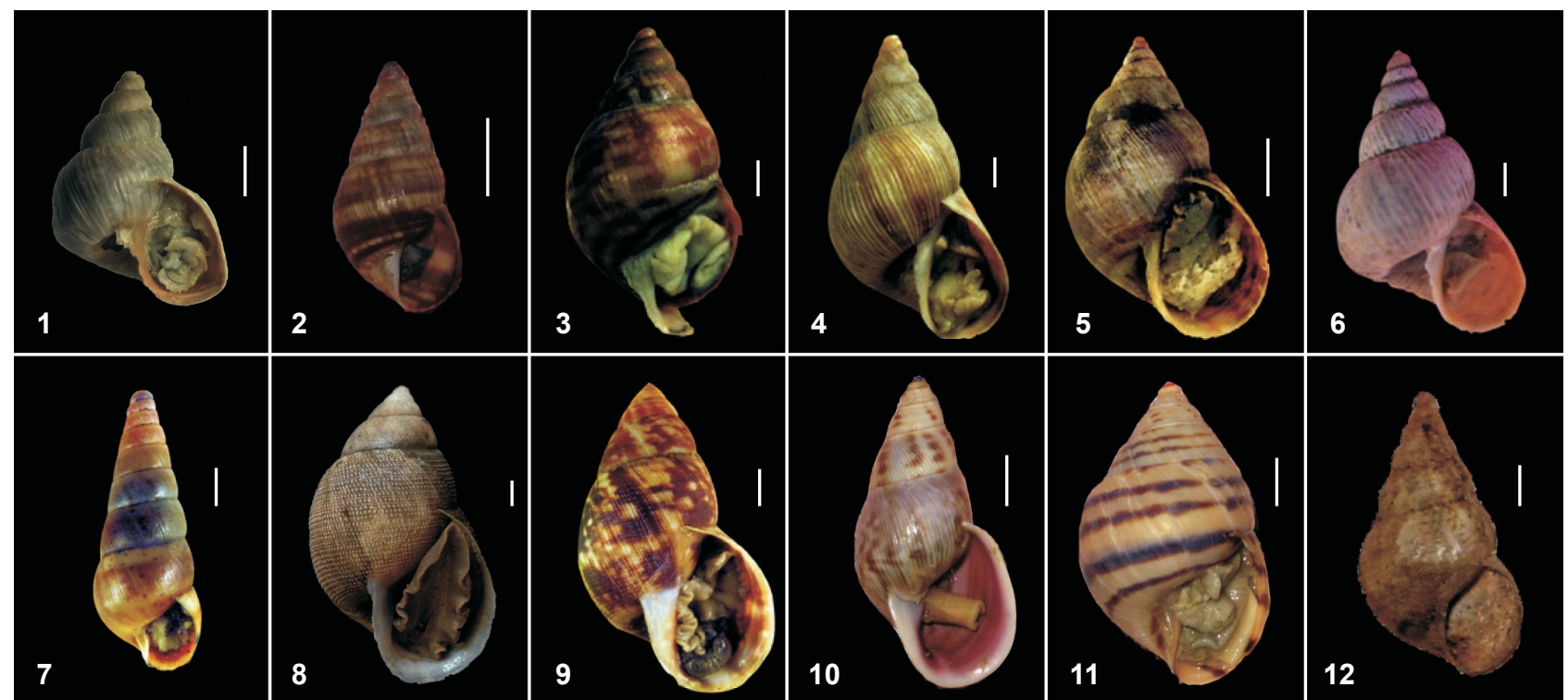

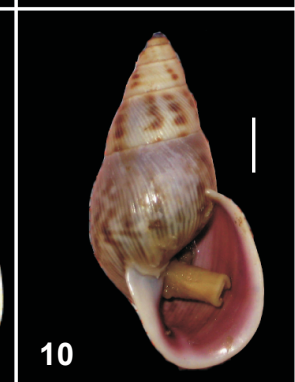

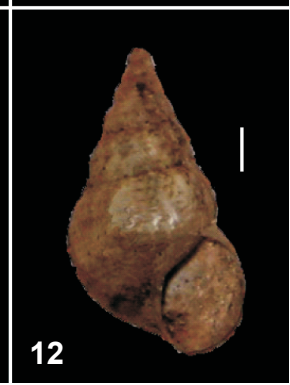

Figures 1-12. Species of Bulimulidae analyzed in this work: (1) Bostryx solutes, MUSM 5515-82G1; (2) B. aguilari MUSM 5501-42A3; (3) B. conspersus MUSM 5505-23F1; (4) B. modestus MUSM 5507-74F1; (5) B. sordidus MUSM 5511-14A15; (6) B. scalariformis MUSM 551075.3; (7) B. turritus MUSM 5514-1F1; (8) Scutalus proteus MUSM 5519-35G1; (9) S. versicolor MUSM 5518-11.8; (10) Drymaeus arcuatostriatus MUSM 5516-59Eu; (11) Neopetraeus tessellates MUSM 4020-62E1; (12) Naesiotus geophilus MUSM 5517-18G1. Photographs: 1 and 8 by D. Maldonado; 2, 10 and 11 by J. Ramirez; 3-7 by A. Chumbe; and 12 by V. Borda. Escale bars: 1, 3, 4, 6, 7, $12=2$ mm; 2, 5, 8-11 = 5 mm. 
Table I. Voucher information and GenBank accession numbers for individuals included in the analyses. Sequences generated for this study are in bold. MUSM: Museum of Natural History, San Marcos University.

\begin{tabular}{|c|c|c|c|c|}
\hline Species & Population & Voucher MUSM & $\begin{array}{c}\text { GenBank } \\
\text { accession 16S }\end{array}$ & $\begin{array}{c}\text { GenBank accession } \\
\text { LSU } 1-3\end{array}$ \\
\hline \multirow[t]{13}{*}{ Bostryx aguilari Weyrauch, 1967} & Lima: Amancaes ${ }^{1}$ & MUSM 5501-42A3 & HQ225813 & HM116230 \\
\hline & Lima: Amancaes' & MUSM 5501-43A6 & HQ225814 & \\
\hline & Lima: Amancaes ${ }^{1}$ & MUSM 5500-53.10 & HQ225815 & \\
\hline & Lima: Amancaes ${ }^{4}$ & MUSM 5041-Ama3 & JQ669492 & \\
\hline & Lima: Iguanil' ${ }^{1}$ & MUSM 5504-29A & HQ225820 & JQ669461 \\
\hline & Lima: Iguanil' & MUSM 5504-31A & HQ225821 & \\
\hline & Lima: Iguanil' & MUSM 5504-26A & HQ225819 & \\
\hline & Lima: Iguanil' & MUSM 5504-32A & HQ225822 & \\
\hline & Lima: Atocongo' ${ }^{1}$ & MUSM 5503-25F1 & HQ225816 & \\
\hline & Lima: Atocongo ${ }^{1}$ & MUSM 5502-17F5 & HQ225817 & \\
\hline & Lima: Atocongo' ${ }^{1}$ & MUSM 5502-19F8 & HQ225818 & \\
\hline & Lima: Atocongo' ${ }^{1}$ & MUSM 5505-23F1 & HМ057172 & JQ669462 \\
\hline & Lima: Atocongo ${ }^{4}$ & MUSM 5042-Atoc39 & JQ669493 & \\
\hline \multirow[t]{3}{*}{ Bostryx conspersus (Sowerby, 1833) } & Lima: Atocongo' ${ }^{1}$ & MUSM 5505-23F1 & HМ057173 & \\
\hline & Lima: Iguanil' & MUSM 5036-lg5 & & JQ669463 \\
\hline & Lima: Lachay ${ }^{1}$ & MUSM 5506-51G3 & JQ669456 & JQ669464 \\
\hline \multirow[t]{2}{*}{ Bostryx modestus (Broderip, in Broderip \& Sowerby 1832) } & Lima: Atocongo ${ }^{1}$ & MUSM 5507-74F1 & HМ057174 & \\
\hline & Lima: Paraiso' ${ }^{1}$ & MUSM 5508-6F1 & JQ669457 & JQ669465 \\
\hline \multirow[t]{3}{*}{ Bostryx scalariformis (Broderip, in Broderip \& Sowerby 1832) } & Lima: Pasamayo' ${ }^{1}$ & MUSM 5510-75.3 & HМ057181.1 & JQ669466 \\
\hline & Lima: N Pan American Hwy Km 115' & MUSM 5509-83.a & Fj969796.1 & \\
\hline & Lima: N Pan American Hwy Km 115' & MUSM 5509-84.b & & JQ669467 \\
\hline \multirow[t]{2}{*}{ Bostryx solutus (Troschel, 1847) } & Lima: Infiernillo² & MUSM 5515-82G1 & JQ669458 & JQ669468 \\
\hline & Lima: Infiernillo² & MUSM 5515-80G6 & HQ225824 & \\
\hline \multirow[t]{3}{*}{ Bostryx sordidus (Lesson, 1826) } & Lima: Iguanil'1 & MUSM 5511-14A15 & HМ057176.1 & \\
\hline & Lima: Lupin ${ }^{1}$ & MUSM 5512-62.12 & FJ969797.1 & \\
\hline & Lima: Santa Eulalia ${ }^{2}$ & MUSM 5513-77E5 & JQ669459 & JQ669469 \\
\hline Bostryx bilineatus (Sowerby, 1833) & Ecuador $^{5}$ & & & HM027501 \\
\hline Bostryx strobeli (Parodiz, 1956) & Argentina $^{5}$ & & & HM027498 \\
\hline Bulimulus guadalupensis (Bruguière, 1789) & Puerto Rico ${ }^{6}$ & & & AY841298 \\
\hline Bulimulus tenuissimus (Férussac, 1832) & Brazil ${ }^{5}$ & & & HM027507 \\
\hline Bulimulus sporadicus (d'Orbigny, 1835) & Brazil $^{6}$ & & & AY841299 \\
\hline Clessinia pagoda Hylton Scott, 1967 & Argentina $^{5}$ & & & HM027497 \\
\hline Drymaeus discrepans (Sowerby, 1833) & Guatemala $^{6}$ & & & AY841300 \\
\hline Drymaeus inusitatus (Fulton, 1900) & Costa Rica ${ }^{5}$ & & & HM027503 \\
\hline Dryamaues laticinctus (Guppy, 1868) & Dominica $^{5}$ & & & HM027492 \\
\hline Drymaeus serratus (Pfeiffer, 1855) & Peru $^{5}$ & & & HM027499 \\
\hline Drymaeus arcuatostriatus (Pfeiffer, 1855) & San Martin: Juan Guerra ${ }^{3}$ & MUSM 5516-59Eu & HM057178 & JQ669472 \\
\hline Naesiotus quitensis (Pfeiffer, 1848) & Ecuador $^{5}$ & & & HM027510 \\
\hline Naesiotus stenogyroides (Guppy, 1868) & Dominica $^{5}$ & & & HM027494 \\
\hline Naesiotus geophilus Weyrauch, 1967 & San Martin: Juan Guerra ${ }^{3}$ & MUSM 5517-18G1 & HМ057180 & \\
\hline Neopetraeus tessellatus (Shuttleworth, 1852) & Ancash: nr. Pontó ${ }^{2}$ & MUSM 4020-62E1 & HМ057179 & JQ669473 \\
\hline Plagiodontes multiplicatus Döring, 1874 & Argentina $^{5}$ & & & HM027496 \\
\hline Scutalus proteus (Broderip, in Broderip \& Sowerby 1832) & Lima: Santa Eulalia ${ }^{2}$ & MUSM 5519-35G1 & HQ225823 & JQ669474 \\
\hline Scutalus versicolor (Broderip, in Broderip \& Sowerby 1832) & Lima: Mongón' & MUSM 5518-11.8 & FJ969798 & JQ669475 \\
\hline Spixia popana Döring, 1876 & Argentina ${ }^{5}$ & & & HM027502 \\
\hline Placostylus bivaricosus (Gascoin, 1885) & Lord Howe Island ${ }^{7}$ & & & AY165846 \\
\hline Placostylus bivaricosus (Gascoin, 1885) & Lord Howe Island ${ }^{7}$ & & & AY165850 \\
\hline
\end{tabular}

${ }^{1}$ Lomas, ${ }^{2}$ Andean region, ${ }^{3}$ Tropical forest, ${ }^{4} \mathrm{R}$. Ramírez (unpublished data), ${ }^{5}$ Breure et al. (2010), ${ }^{6}$ WADE et al. (2006); ${ }^{7}$ PONDER et al. (2003). 
Sequences of the mitochondrial 16S rRNA and nuclear rRNA regions were obtained for 12 and 11 species of Bulimulidae, respectively, including seven species of Bostryx. Eleven sequences of the partial 16S rRNA gene were obtained from different populations of B. aguilari; three samples were sequenced with the LSU1/LSU3 primer pair. Nineteen sequences were retrieved from GenBank. Voucher information and GenBank accession numbers are given in Table I.

Sequences were edited with Chromas (McCarthy 1996), assembled with CAP3WIN (HUANG \& MADAN 1999), aligned with ClustalX 2.0 (LARKIN et al. 2007) and adjusted manually in BioEdit v7.0.9 (HALL 1999). Gaps were treated as a fifth character. For the phylogenetic analyses we used, in addition to our data, seven sequences of the nuclear marker retrieved from GenBank (Table I). We were very careful when aligning the $16 \mathrm{~S}$ rRNA marker, because it has a high mutation rate and indels are extremely common. In order to get a better hypothesis of homology, we used the secondary structure of the 16S rRNA of Albinaria caerulea (LyDEARD et al. 2000, RAMIREZ \& RAMíREZ 2010) as a template for the alignment.

Different phylogenetic analyses were performed. The cladogram for all taxa was constructed using Neighbor-Joining (NJ) (Saitou \& Nei 1987) as implemented in PAUP* $4.0 b 10$ (SwOFFord 2003). Tree searching was heuristic, with tree-bisection-reconnection branch swapping. Branch support was evaluated using bootstrap resampling (FelsensteIn 1985) with 1,000 replicates. Maximum Parsimony (MP) was implemented using PAUP* 4.0b10 (SwOFFord 2003), initial heuristic searches were conducted with random stepwise addition, Tree-BisectionReconnection (TBR) branch swapping, and bootstrap with 1,000 replicates. Maximum Likelihood (ML) analyses were conducted using heuristic search, the initial tree was obtained by stepwise addition and TBR in PAUP* 4.0b10. Support for nodes was estimated with 1,000 bootstrap replicates. The nucleotide substitution model, base frequencies, proportion of invariant sites and shape parameter of the gamma distribution were estimated based on Akaike criterion using JModeltest (Posada 2008). Bayesian inference (BI) was performed using MrBayes 3.1.2 (RonQUIST \& HuelsenbeCK 2003); four chains of a Markov Chain Monte Carlo algorithm were run simultaneously for 10 million generations, sampled every 1,000 generations, and burn-in of 9,000 generations. A consensus tree and final posterior probabilities were calculated using the remaining trees. The tree based on 16S rRNA was rooted using Placostylus (Placostylidae). For the nuclear rRNA gene-cluster, trees were rooted using species belonging Odontostomidae, which is sister to Bulimulidae according to BREURE et al. (2010).

Sequences of Bostryx aguilari were evaluated in DAMBE v5.0.8 (XIA \& XIE 2001). We calculated nucleotide frequencies, percentage of CpG islands, percentage of CG and the extent of saturation, by plotting pairwise genetic distances against the distribution of transitions and transversions. Values of genetic diversity, such as haplotype diversity $(h)$ and nucleotide diver- sity $(\pi)$ were obtained using DnaSP v5.10 (LIBRADo \& Rozas 2009). Pairwise distances were obtained in MEGA v4.02 (Kumar et al. 2008) including all positions and using a Maximum Composite Likelihood method. Relationships among haplotypes of the 16S rRNA marker were evaluated using the Median Joining algorithm obtained in Network 4.5.1.0 (BANDELT et al. 1999). Fst statistics was calculated using Arlequin v3.11. In order to estimate the time to most recent common ancestor (TMRCA) for B. aguilari, we calibrated a Linearized $\mathrm{NJ}$ tree for a conservative rate for terrestrial mollusks ( 0.06 substitutions per site per million years) for the $16 \mathrm{~S}$ rRNA, using MEGA (ExCOFFIER et al. 2005).

\section{RESULTS}

\section{Interspecific phylogeny}

The alignment generated for the phylogenetic reconstruction of the partial 16S rRNA gene consisted of 26 sequences (only the four haplotypes of B. aguilari were used) corresponding to 13 species of Bulimulidae. This alignment had 382 positions, with 202 variable sites (of which 179 were informative), 170 conserved sites, and 22 singletons. The nucleotide substitution model selected was TPM1uf+G. For the nuclear rRNA, the alignment of 29 sequences resulted in 868 sites, 656 of which were conserved and 199 were variable sites (158 informative), and 41 were singletons. The nucleotide substitution model selected was GTR+G.

Phylogenetic reconstructions based on the partial 16S rRNA gene using NJ, MP, ML and BI resulted in trees with similar topologies (Fig. 13). The group of species known as the "Bostryx modestus species complex", which includes B. modestus, B. sordidus and B. scalariformis (R. Ramírez unpublished data), was strongly supported in our analyses. It grouped along with B. solutus, B. aguilari, and B. conspersus with weak to strong support. However, B. turritus did not cluster with any other species of Bostryx. Regarding the phylogenetic analyses using the nuclear rRNA marker, again the four phylogenetic methods used yielded trees with similar topologies (Fig. 14). Bulimulidae was supported by maximum values. The sequences of B. modestus, B. scalariformis, and B. sordidus (B. modestus species complex) grouped with strong support. The $B$. modestus species complex, along with $B$. solutus, $B$. conspersus, and $B$. aguilari grouped together with strong support. Neopetraeus and Drymaeus formed a monophyletic group with good to strong support. Naesiotus quitensis and Bostryx strobeli clustered with strong support and, in our data, formed a strongly supported monophyletic group with Bulimulus.

The trees obtained with the two markers have similar topologies. Both trees grouped B. solutus with B. modestus species complex, B. aguilari and B. conspersus.

\section{Genetic diversity of Bostryx aguilari}

The alignment of 14 sequences of the partial 16S rRNA gene of B. aguilari resulted in 345 sites without indels. There were three variable sites, which were informative. By compar- 


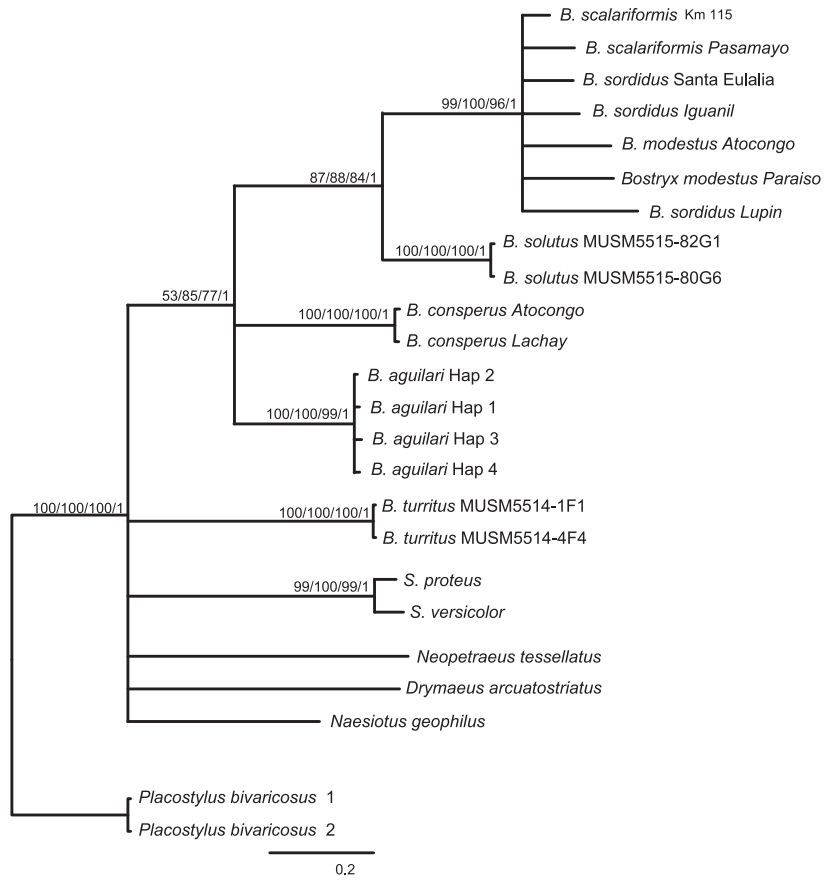

Figure 13. Phylogenetics relationships based on the 16S rRNA. Numbers correspond to bootstrap values for Neighbor-Joining, Maximum Parsimony and Maximum Likelihood, respectively, and posterior probabilities for Bayesian inference. Only nodes with bootstrap values greater than $50 \%$ and posterior probabilities of 0.9 are represented.

ing these sequences with other Bulimulids, we were able to observe the presence of several indels up to $4 \mathrm{bp}$ long. This region of the mitochondrial genome of $B$. aguilari is larger than that found in other Bostryx from Lomas, as well as in other genera of Bulimulidae evaluated so far (4 to $23 \mathrm{bp}$ difference). The nucleotide composition showed a predominance of AT (71.66\%) over GC (28.34\%). Sequences obtained for the nuclear rRNA were 826 bp long. The three individuals had the same haplotype. The percentage of GC (55.83\%) was slightly higher than that of AT.

The 14 16S rRNA sequences collapsed into four haplotypes. The haplotype diversity $(h)$ was 0.7802 and $\pi$ was 0.00347 . By comparing these results with values found for other species of Bostryx from Lomas (R. Ramírez unpublished data), we observed that $B$. aguilari has the lowest values of haplotype diversity. The haplotype network in Figure 15 shows a correlation between haplotypes and the geographic distribution of $B$. aguilari, revealing the Atocongo population as the only one with unique haplotypes. The Amancaes population showed only one haplotype, which was shared with an individual from Iguanil, in spite of the geographic distance $(70 \mathrm{~km})$ and the apparent absence of intermediate populations between the two Lomas (no live individuals or shells recorded). The individual

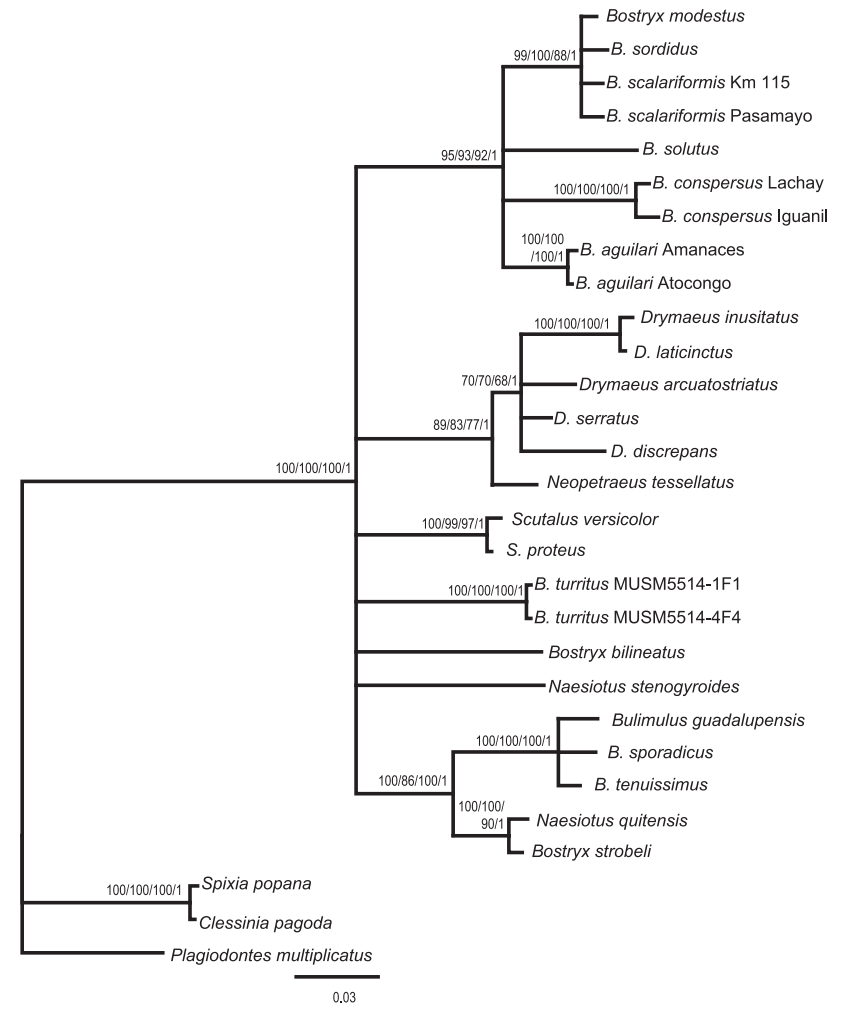

Figure 14. Phylogenetics relationships based on the nuclear rRNA gene cluster. Numbers represent bootstrap values for NeighborJoining, Maximum Parsimony and Maximum Likelihood, respectively, and posterior probabilities for Bayesian inference. Only nodes with bootstrap values greater than $50 \%$ and posterior probabilities of 0.9 are represented.

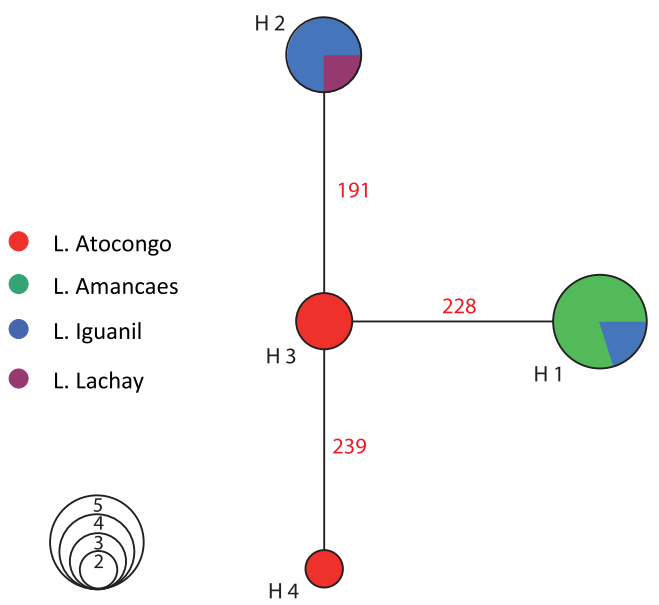

Figure 15. Haplotype Network based on 16S rRNA of B. aguilari. Circles are proportional to frequencies. Colors indicate locality of samples. There is only one mutation between haplotypes. Numbers indicate the position of mutation in the alignment. 
from Lachay shared its haplotype with individuals from Iguanil. These haplotypes are differentiated by a single mutational step between them. The Fst analyses showed significant values only between Atocongo and the remaining populations. The TMRCA for $B$. aguilari was estimated in 38,565 years.

\section{DISCUSSION}

\section{The polyphyly of Bostryx}

BREURE (1979) conducted a study on evolutionary relationships and geographic distribution of the genera in Bulimulinae. More recently, molecular studies have shed new light on the diversity and the relationships within the land snails (WADE \& MORDAN 2000, WADE et al. 2001, 2006) and within Orthalicoidea (Ponder et al. 2003, Parent \& Crespi 2006, Herbert \& Mitchell 2009, Ramirez et al. 2009, Breure et al. 2010, Buckley et al. 2011). BReure et al. (2010), after revisiting the phylogeny of Orthalicoidea, found that Orthalicidae and Amphibulimulidae are the most basal families, whereas Placostylidae is basal to the clade consisting of Odontostomidae and Bulimulidae.

Bostryx belongs to Orthalicidae, after Bouchet \& RocroI (2005), which is composed of several subfamilies, including Bulimulinae. This subfamily had been considered as a separate family by several authors (VAUGHT 1989). In this study, we considered Bostryx as a member of Bulimulidae, following BREURE $e t$ al. (2010). In our analyses based on the nuclear rRNA, we added more genera and species to the set of taxa analyzed by BREURE $e t$ al. (2010), and confirmed that Bulimulidae is clearly a monophyletic group, and that Bostryx is a member of this family. Our results, obtained with both nuclear and mitochondrial markers, show that the B. modestus species complex, B. aguilari and $B$. conspersus, is related to $B$. solutus, a land snail that lives at $3300 \mathrm{~m}$ in the Western Andes. The position of B. turritus, a Peruvian species found in Inter-Andean valleys, was not resolved, showing low support for any relationships with the other Bostryx species analyzed. The monophyly of Bostryx was not supported by the different analyses. It is important to note that Bostryx was described using Bostryx solutus as the type species (BReure 1979). Bostryx solutus was recovered in a strongly supported group together with B. aguilari, B. conspersus, $B$. modestus, $B$. scalariformis, and $B$. sordidus. These results suggest that only this group should be considered as Bostryx. More studies are needed to establish the position of $B$. turritus, as well as the other two species of Bostryx (B. bilineatus and B. strobeli) included in the nuclear analyses.

\section{Genetic diversity of Bostryx aguilari}

Bostryx aguilari had the lowest value of haplotype diversity compared to other species of Bostryx from Lomas. This may be due to the small size of the populations (suggested by the extreme difficulty in locating live individuals), and their possible recent origin. To compare other values of genetic diversity such as $\pi$, we examined the work of P. Romero (unpublished data), where a value of 0.04028 for $\pi$ was found for popula- tions of $B$. scalariformis. This is about 10 times higher than what was observed for B. aguilari. P. Romero found intraspecific distance values up to 0.0608 for $B$. scalariformis, while the maximum value found for B. aguilari was 0.006 .

The distribution of the 16S rRNA haplotypes of B. aguilari and Fst values are consistent with results reported by R. Ramírez (unpublished data) regarding the variation of shells, and revealed the population of Atocongo as the most differentiated. The fact that an individual from Amancaes shared its haplotype with individuals from Iguanil, two distant Lomas and without intermediate populations of $B$. aguilari, suggests a recent origin of these populations from a common ancestor. The possibility that this distribution is due to an event of recent geographic expansion after a genetic bottleneck (from refuge) cannot be discarded. The single individual of B. aguilari from Lachay shared the same haplotype with individuals from Iguanil. Coupled with the proximity of these Lomas $(17 \mathrm{~km})$, we propose a likely phenomenon for the historic gene flow between them. The occurrence of ENSO events could allow the establishment of corridors connecting Lomas that are considered islands of vegetation (RAMírez et al. 2003b).

Several ENSO events have left their marks on the genetic structure of populations of land snails from Lomas. ENSO events of greater magnitude have changed dramatically the landscape of the desert, generating larger Lomas and even connecting adjacent Lomas, whereas in dry periods and ENSO of low intensity, Lomas would become a refuge for these species (RAmírez et al. 2003b). Both Tudhope et al. (2001) and La TorRe et al. (2002) reported a strong ENSO about 40 thousand years, which agrees with the estimated date for the geographical expansion of $B$. aguilari.

\section{Implications for Conservation}

The Lomas are unique ecosystems in the world. They harbor endemic species whose restricted distribution has been caused by different historical processes (drastic climatic changes, population expansion, bottlenecks, isolation of populations by physical barriers, etc.). Unfortunately, humans have started to invade and occupy different Lomas, threatening the local biodiversity. For instance, cities are an almost insurmountable physical barrier to desert species, generating a new type of isolation that cannot be overcome by periodic favorable conditions of the ENSO. In most localities where B. aguilari has been reported, live individuals could not be found, and in those where they were found alive, their numbers were low. Atocongo was an exception to this rule, as it had a larger number of individuals, greater variation in shells, and a more differentiated population with exclusive haplotypes. Major conservation efforts should be applied to this area, which is currently threatened by the expansion of shanty towns, and which has been temporarily put under the custody of a cement factory performing work in the area; the company has surrounded the place with a concrete fence to prevent imminent invasions by the surrounding shanty towns. A worrying situation is found 
in the Lomas of Amancaes, B. aguilari was originally reported for this Loma from 200 to $600 \mathrm{~m}$, and at the present time the Loma is virtually occupied by urbanization up to the 400 meters, being restricted to a fraction of the original size. Due to the damage that these incursions cause, as well as the scarce conservation efforts, it is not difficult to imagine the immediate future of this ecosystem. A different picture is seen in Lachay and Iguanil; Lachay is a National Reserve of great extension (5070 ha.) and Iguanil is far from the city and surrounded by farming communities. Both Lomas guarantee the conservation of part of the low diversity of B. aguilari, whose populations are the most distinct besides Atocongo. Bostryx aguilari is considered a rare species that has low genetic diversity and small populations. Therefore, there is an urgent need to increase conservation efforts, which should focus on stopping the degradation of its habitat.

\section{ACKNOWLEDGMENTS}

We thank A. Chumbe, C. Congrains, D. Fernandez, J. Chirinos, N, Medina, P. Matos and P. Romero for assistance during laboratory and field work. We thank A. Chumbe, D. Maldonado and V. Borda for provided photographs of species. We also thank to M. Arakaki for helping to improve a former version of the manuscript. This study was sponsored by the Instituto de Investigación en Ciencias Biológicas Antonio Raimondi (ICBAR), and funded by Consejo Superior de Investigaciones (CSI) of Vicerrectorado Académico, UNMSM (061001071, 071001221).

\section{LITERATURE CITED}

Aguilar, P. \& J. Arrarte. 1974. Moluscos de las lomas costeras del Perú. Anales Científicos, Universidad Nacional Agraria, (Perú) 12 (3-4): 93-98.

Bandelt, H.; P. Forster \& A. RöHl. 1999. Median-joining networks for inferring intraspecific phylogenies. Molecular Biology and Evolution 16: 37-48.

BREURE, A. 1979. Systematics, phylogeny and zoogeography of Bulimulinae (Mollusca). Zoologische Verhandelingen 168: $1-215$.

Breure, A.; D. Groenenberg \& M. Schilthuizen. 2010. New insights in the phylogenetic relations within the Orthalicoidea (Gastropoda, Stylommatophora) based on $28 \mathrm{~S}$ sequence data. Basteria 74 (1-3): 25-32.

Bouchet, P. \& J. Rocroi. 2005. Classification and Nomenclator of Gastropod Families. Malacologia 47: 1-2.

Buckley, T.R.; I. Stringer; D. Gleeson; R. Howitt; D. Attanayake; R. Parrish; G. Sherley \& M. Rohan. 2011. A revision of the New Zealand Placostylus land snails using mitochondrial DNA and shell morphometric analyses, with implications for conservation. New Zealand Journal of Zoology 38 (1): 55 81.
Dillon, M.; M. NaKazawa \& S. Leiva. 2003. The Lomas formations of coastal Peru: Composition and biogeographic history. Fieldiana Botany 43: 1-9.

DoyLe, J.J. \& J.L. DoyLe. 1987. A rapid DNA isolation procedure for small amounts of fresh leaf tissue. Phytochemical Bulletin 19: 11-15.

Excoffier, L.; G. Laval \& S. Schneider. 2005. Arlequin ver. 3.0: An integrated software package for population genetics data analysis. Evolutionary Bioinformatics Online 1: 47-50.

Felsenstein, J. 1985. Confidence limits on phylogenies: an approach using the bootstrap. Evolution 39: 783-791.

HALL, T. 1999. BioEdit: a user-friendly biological sequence alignment editor and analysis program for Windows 95/98/ NT. Nucleic Acids Symposium Series 41: 95-98.

Herbert, D. \& A. Mitchell. 2009. Phylogenetic relationships of the enigmatic land snail genus Prestonella - the missing African element in the Gondwanan superfamily Orthalicoidea (Mollusca: Stylommatophora). Biological Journal of the Linnean Society 96: 203-221.

Huang, X. \& A. Madan. 1999. CAP3: A DNA Sequence Assembly Program. Genome Research 9: 868-877.

Kumar, S.; J. Dudley; M. Nei \& K. Tamura. 2008. MEGA: A biologist-centric software for evolutionary analysis of DNA and protein sequences. Briefings in Bioinformatics 9: 299306.

La Torre, C.; J. Betancourt; K. Rylander \& J. Quade. 2002. Vegetation invasions into absolute desert: A $45000 \mathrm{yr}$ rodent midden record from the Calama-Salar de Atacama basins, northern Chile (lat 228-248S). GSA Bulletin 114 (3): 349366.

Larkin, M.; G. Blackshields; N. Brown; R. Chenna; P. Mcgettigan; H. Mcwilliam; F. Valentin; I. Wallace; A. Wilm; R. Lopez; J. Thompson; T. Gibson \& D. Higgins. 2007. Clustal W and Clustal $X$ version 2.0. Bioinformatics 23: 2947-2948.

Librado, P. \& J. Rozas. 2009. DnaSP v5: A software for comprehensive analysis of DNA polymorphism data. Bioinformatics 25: 1451-1452.

Lydeard, C.; W. Holznagel; M. Schnare \& R. Gutell. 2000. Phylogenetic analysis of molluscan mitochondrial LSU rDNA sequences and secondary structures. Molecular Phylogenetics and Evolution 15: 83-102.

Mccarthy, C. 1996. Chromas: version 1.3. Brisbane, Griffith University.

Parent, C.E. \& B.J. Crespr. 2006. Sequential colonization and diversification of Galápagos endemic land snail genus Bulimulus (Gastropoda, Stylommatophora). Evolution 60: 2311-2328.

Ponder, W.; D. Colgan; D. Gleeson \& G. Sherley. 2003. The relationships of Placostylus from Lord Howe Island. Molluscan Research 23: 159-178.

Posada, D. 2008. jModelTest: phylogenetic model averaging. Molecular Biology and Evolution 25: 1253-1256.

Ramirez, J. \& R. RAMíREZ, 2010. Utility of secondary structure of 
mitochondrial LSU rRNA in the phylogenetic reconstruction for land snails (Orthalicidae: Gastropoda). Revista Peruana de Biología 17 (1): 53-57.

Ramirez, J.; R. Ramírez; P. Romero; A. Chumbe \& P. Ramírez. 2009. Posición evolutiva de caracoles terrestres peruanos (Orthalicidae) entre los Stylommatophora (Mollusca: Gastropoda). Revista Peruana de Biología 16 (1): 51-56.

Ramírez, R.; C. Paredes \& J. Arenas. 2003a. Moluscos del Perú. Revista de Biologia Tropical 51 (3): 225-284.

Ramírez, R.; S. Córdova; K. Caro \& J. Dú́rez. 2003b. Response of a land snail species (Bostryx conspersus) in the Peruvian Central Coast Lomas Ecosystem to the 1982-1983 and 1997-1998 El Niño events. Fieldiana, Botany 43: 10-23.

Ronquist, F. \& J. Huelsenbeck. 2003. MrBayes 3: Bayesian phylogenetic inference under mixed models. Bioinformatics 19 (12): 1572-1574.

Rundel, P.; M. Dillon; B. Palma; H. Mooney; S. Gulmon \& J.R. Ehleringer. 1990. The Phytogeography and Ecology of the Coastal Atacama and Peruvian Deserts. Aliso 13 (1): 1-50.

Saiki, R.; D. Gelfand; S. Stoffel; S. Scharfj; R. Higuchi; G. Horn; K. Muldis \& H. ERlich. 1988. Primer-directed enzymatic amplification of DNA with a thermostable DNA polymerase. Science 239: 487-491.

Saitou, N. \& M. Nei. 1987. The neighbor-joining method: A new method for reconstructing phylogenetic trees.
Molecular Biology and Evolution 4: 406-425.

Swofford, D. L. 2003. PAUP*. Phylogenetic Analysis Using Parsimony (*and Other Methods). Sunderland,Sinauer Associates, version 4 .

Tudhope, A.; C. Chilcott; M. Mcculloch; E. Cook; J. Chappell; R. Ellam; D. Lea; J. Lough \& G. Shimmield. 2001. Variability in the El Niño-Southern Oscillation through a glacialinterglacial cycle. Science 291: 1511-1517.

VAught, K. 1989. A classification of the living Mollusca. Melbourne, American Malacologist Inc.

XIA, X. \& Z. XIE. 2001. DAMBE: Data analysis in molecular biology and evolution. Journal of Heredity 92: 371-373.

WADE, C. \& P. MoRdan. 2000. Evolution within the gastropod mollusks; using the ribosomal RNA gene-cluster as an indicator of phylogenetic relationships. Journal of Molluscan Studies 66: 565-570.

Wade,C; P. Mordan \& B. Clarke. 2001. A phylogeny of the land snails (Gastropoda: Pulmonata). Proceedings of the Royal Society of London Series B 268: 413-422.

WADE, C.; P. Mordan \& F. NAGgs. 2006. Evolutionary relationships among the Pulmonate land snails and slugs (Pulmonata, Stylommatophora). Biological Journal of the Linnean Society 87(4): 593-610.

Weyrauch, W. 1967. Treinta y Ocho Nuevos Gastropodos Terrestres de Perú. Acta Zoológica Lilloana 21: 349-351.

Submitted: 09.V.2012; Accepted: 17.VII.2012.

Editorial responsibility: Marcos D.S. Tavares 